Postgraduate Bosowa University Publishing (PBUP)
Indonesian Journal of Business and Management
e-ISSN: $2460-3767 \quad p$-ISSN: $2656-6885$
Pttps://postgraduate.universitasbosowa.ac.id/index.php/jbm

\title{
ANALISIS STRATEGI BERSAING PRODUK KREDIT KEPEMILIKAN KENDARAAN BERMOTOR PADA PT. BANK RAKYAT INDONESIA (PERSERO)TBK KANTOR WILAYAH MAKASSAR
}

\author{
Competitive Strategy Analysis of Ownership Credit Products of Motor Vehicle at PT. Bank Rakyat \\ Indonesia (persero) Tbk, Makassar Regional Office
}

\author{
Alfian Setiawan ${ }^{1}$, Muhlis Ruslan², Herminawati Abubakar ${ }^{2}$ \\ ${ }^{1}$ Mahasiswa Magister Manajemen Universitas Universitas Bosowa \\ ${ }^{2}$ Program Studi Manajemen Program Pascasarjana Universitas Bosowa
}

Email: 4lfian.setiawan@gmail.com

Diterima: 04 April 2020/Disetujui: 05 Juni 2020

\begin{abstract}
ABSTRAK
Penelitian ini bertujuan untuk mengidentifikasi dan menganalisis faktor lingkungan internal (kekuatan dan kelemahan) dan faktor lingkungan eksternal (peluang dan ancaman).. Metode pengumpulan data terdiri dari observasi, wawancara, dokumentasi dan kuisioner. Populasi dan sampel dalam penelitian ini terdiri dari 44 Karyawan dengan teknik non probability sampling menggunakan metode sampling jenuh. Metode analisis data yang digunakan yaitu analisis deskriptif dan analisis swot. Hasil Penelitian menemukan bahwa faktor kekuatan (internal) yakni harga produk yang ditetapkan terjangkau konsumen memiliki skor nilai tinggi dibandingkan kualitas produk yang ditawarkan, pengaruh lokasi terhadap kelangsungan usaha, pelayanan kepada konsumen, jaminan kualitas produk, dan kerjasama yang baik dengan pihak asuransi. Sedangkan pada faktor kelemahan (internal) yakni keterbatasan jumlah karyawan yang tinggi memiliki skor paling tinggi dibadingkan dengan tingkat harga kredit kendaraan yang ditawarkan dan resiko penurunan pendapatan yang tinggi. Untuk faktor Peluang (eksternal) yang memiliki skor paling tinggi yakni perusahaan memiliki keunggulan dalam menangkap pangsa pasar yang baik dibandingkan dengan jalinan kerjasama perusahaan dengan konsumen, dampak positif dari keragaman produk yang ditawarkan, citra perusahaan yang baik dimata konsumen, respon positif konsumen terhadap jasa perusahaan, tingkat daya beli masyarakat, dan tingkat permintaan pasar.Sedangkan untuk faktor ancaman (eksternal) yakni tingkat persaingan usaha yang tinggi memiliki skor paling tinggi dibandingkan resiko usaha jasa kredit kendaran yang tinggi, resiko pekerja freelance yang tinggi, tuntutan pasar dalam peremajaan kendaraan yang tinggi, tingkat kriminalitas pencurian kendaraan yang tinggi dan tingginya pertumbuhan usaha kredti kendaraan disekitar.Secara garis besar dari ke empat faktor tersebut faktor Kekuatan dan Peluang masih memiliki skor yang lebih tinggi dibandingkan dengan faktor Kelemahan dan Ancaman sehingga PT Bank Rakyat Indonesia (Persero) Tbk berada dalam posisi yang baik.
\end{abstract}

Kata Kunci: Strategi; Persaingan; Produk, Kredit, BRI

\section{ABSTRACT}

This study aims to identify and analyze the internal environmental factors (strengths and weaknesses) and external environmental factors (opportunities and threats). Data collection methods consist of observation, interviews, documentation and questionnaires. The population and sample in this study consisted of 44 employees with a nonprobability sampling technique using a saturated sampling method. The data analysis method used is descriptive analysis and SWOT analysis. The results of the study found that the strength factor (internal), namely the price of the product that is determined to be affordable by consumers, has a high score compared to the quality of the product offered, the effect of location on business continuity, service to consumers, product quality assurance, and good cooperation with the insurance company. Meanwhile, the weakness (internal) factor, namely the limited number of high employees, has the highest score compared to the price level of vehicle loans offered and the risk of a high decline in income. For the Opportunity (external) factor, the highest score is the company that has the advantage of capturing a good market share compared to the 
company's collaboration with consumers, the positive impact of the diversity of products offered, a good corporate image in the eyes of consumers, positive consumer responses to company services, the level of public purchasing power, and the level of market demand. As for the threat factor (external), the high level of business competition has the highest score compared to the risk of high vehicle credit service business, high risk of freelance workers, high market demands in vehicle rejuvenation, the high level of vehicle theft crime and the high growth of the surrounding vehicle credit business. Broadly speaking, of the four factors, the Strength and Opportunity factors still have higher scores than the Weakness and Threats factors so that PT Bank Rakyat Indonesia (Persero ) Tbk is in a good position.

Keywords: Strategy; Competition; Product; Credit, BRI

\section{PENDAHULUAN}

Pembangunan disegala bidang merupakan tujuan utama yang sedang giat dilaksanakan dalam rangka terciptanya masyarakat yang adil dan makmur berdasarkan Pancasila dan Undang-Undang Dasar 1945. Dengan dibukanya kesempatan usahayang seluas-luasnya oleh pemerintah kepada masyarakat, maka perkembangan dunia usaha nasional dewasa ini tumbuh dan berkembang dengan pesatnya. Berbagai jenis badan usaha, baik perusahaan pemerintah maupun perusahaan swasta terus bermunculan sehingga dengan sendirinya perkembangan dunia usaha semakin diwarnai dengan persaingan yang semakin ketat. Oleh karena itu, setiap perusahaan dituntut untuk memiliki keunggulan komparatif dan kompetitif untuk tetap dapat menjaga kelangsungan hidup usahanya. Program Pemerintah dalam membangun ekonomi nasional sebagaimana tertera di dalam Garis-Garis Besar Haluan Negara, antara lain dilaksanakan dengan mengembangkan peranan lembaga pembiayaan guna memenuhi tuntutan pembangunan nasional. Lembaga pembiayaan dalam mengembangkan perekonomian Indonesia berperan sebagai mitra pemerintah untuk mencapai tujuannya.

Industri pembiayaan mulai tumbuh di Indonesia pada 1974 dan kelahirannya didasarkan pada surat keputusan bersama (SKB) tiga menteri, yaitu Menteri Keuangan, Menteri Perindustrian, dan Menteri Perdagangan. Kemudian, melalui Keputusan Presiden (Keppres) No.61/1988, yang ditindaklanjuti dengan SK Menteri Keuangan No. 1251/KMK.013/1988, pemerintah membuka lebih luas lagi bagi bisnis pembiayaan, dengan cakupan kegiatan, yang meliputi leasing, factoring, consumer finance, modal ventura, dan kartu kredit. Seiring dengan berjalannya waktu yang semakin maju, maka kebutuhan manusia akan barang dan jasa juga semakin meningkat. Kebutuhan suatu kendaraan merupakan kebutuhan yang dapat memberikan rasa kepuasan tersendiri dalam kelancaran transportasi, terlebih lagi kendaraan roda empat yang dapat digunakan untuk berbagai keperluan seperti transportasi ke tempat kerja, transportasi berbisnis, transportasi rekreasi dan masih banyak keperluan manusia yang lainnya.

Kehadiran berbagai lembaga pembiayaan turut membawa andil yang besar dalam pembangunan ekonomi masyarakat khususnya masyarakat kecil. Berbagai pembiayaan muncul sebagai suatu bentuk penyediaan dana atau barang modal kepada masyarakat untuk pembelian barang yang pembayarannya dilakukan secara angsuran atau berkala oleh konsumen. Munculnya praktek pembiayaan dengan sistem pembiayaan konsumen disebabkan oleh faktor sulitnya bagi sebagian besar masyarakat mempunyai akses untuk mendapatkan kredit yang selalu diikat dengan agunan (Fuady, 2002). Oleh karena itu, peran perbankandalam mendukung kegiatan perekonomian sangat besar. Bank berusaha agar dapat membantu dan mendorong kegiatan perekonomian dengan menyediakan fasilitas kredit yang dapat dijangkau dan sangat dibutuhkan oleh setiap individu dalam masyarakat. Salah satu fasilitas kredit yang dibutuhkan oleh masyarakat tersebut adalah penyediaan Kredit Kepemilikan kendaraan Bermotor (KKB), karena setiap individu membutuhkan kendaraan selain sandang, pangan dan rumah yang mutlak harus dipenuhi setiap individu.

Kota Makassar merupakan salah satu pusat pertumbuhan ekonomi dengan jumlah penduduk yang cukup tinggi yang berada di wilayah timur Indonesia, dimana jumlah penduduknya mengalami peningkataan dari tahun ke tahun. Kota Makassar juga menjadi fokus Bank BRI dalam menyalurkan kredit KKB karena dianggap memiliki potensi besar pemasaran kredit KKB.

Tujuan penelitian ini adalah untuk mengindentifikasi dan menganalisis faktor-faktor lingkungan internal (kekuatan dan kelemahan) produk kredit kepemilikan kendaraan bermotor yang dimiliki PT.Bank Rakyat Indonesia (Persero) Tbk kantor wilayah Makassar, mengindentifikasi dan menganalisis faktor-faktor lingkungan eksternal (peluang dan ancaman) produk kredit kepemilikan kendaraan bermotor yang dimiliki PT.Bank Rakyat Indonesia (Persero) Tbk kantor wilayah Makassar

\section{METODE}

\subsection{Jenis Penelitian}

Penelitian yang digunakan dalam penelitian ini untuk mendapatkan data yang obyektif, valid, dan reliabel dengan tujuan dapat ditemukan, dibuktikan dan dikembangkan suatu pengetahuan, sehingga dapat digunakan untuk memahami, memecahkan dan mengantisipasi masalah yang terjadi. Bertolak dari permasalahan dan tujuan penelitian maka metode penelitian yang digunakan adalah penelitian kuantitatif yaitu penelitian yang dimaksudkan untuk memperoleh informasi mengenai strategi bersaing produk kredit kepemilikan kendaraan bermotor dengan pendekatan SWOT. 


\subsection{Lokasi dan Jadwal Penelitian}

Penelitian ini akan dilakukan di PT Bank Rakyat Indonesia (Persero) Tbk Kantor Wilayah Makassar berlokasi di Jalan Ahmad Yani Kota Makassar. Sedangkan waktu yang digunakan selama melakukan penelitian dan pengumpulan data-data yang digunakan dalam penelitian ini diperkirakan kurang lebih 2(dua) bulan.

\subsection{Jenis dan Sumber Data}

a. Jenis Data, Data kualitatif, yaitu data atau informasi yang diperoleh dalam bentuk bukan angka-angka tetapi dalam bentuk informasi baik lisan maupun tertulis mengenai strategi pemasaran pada BRI Kanwil Makassar dan Data kuantitatif adalah data mengenai angka-angka seperti jumlah nasabah BRI Kanwil Makassar, data pesaing serta data lainnya yang diperoleh dari BRI Kanwil Makassar.

b. Sumber Data, Data primer yang penulis peroleh dilakukan dengan melakukan pengamatan langsung ke tempat penelitian tepatnya pada BRI Kanwil Makassar dan melakukan wawancara dengan pihakpihak yang terkait dalam penelitian ini dan Data sekunder pada peneltian ini berdasarkan dokumen tertulis yang diperoleh dari BRI Kanwil Makassar. Data sekunder ini bersifat internal dimana informasi yang diperoleh secara langsung dari BRI Kanwil Makassar.

\subsection{Populasi dan Sampel}

Menurut Sugiyono (2016) bahwa Populasi adalah wilayah generalisasi yang terdiri atas objek atau subjek yang mempunyai kuantitas dan karakteristik tertentu yang ditetapkan oleh peneliti untuk dipelajari dan kemudian ditarik kesimpulannya.Populasi dalam penelitian ini adalah seluruh karyawan termasuk pengambil kebijakan KKB pada PT Bank Rakyat Indonesia (Persero) Tbk Kantor Wilayah Makassar.

Sampel merupakan bagian dari populasi yang dijadikan sebagai obyek penelitian. sampel dalam penelitian ini terdiri dari 44 Karyawan yang terlibat langsung dalam bisnis Kredit Kendaraan Bermotor orang yang terdiri dari 2 orang Manajer Pemasara, 22 Orang Relationship Manajer, 12 Orang Sales dan 8 Orang Administrasi, yang ditentukan dengan tehnik non probability sampling menggunakan meode sampling jenuh dimana penentuan sampel merupakan semua anggota populai karena jumlah populasinya kecil.

\subsection{Metode Pengumpulan Data}

Untuk memperoleh data yang diperlukan dalam penelitian ini, penulis menggunakan metode pengumpulan data sebagai berikut:

a. Observasi, yaitu melakukan pengumpulan data melalui pengamatan langsung mengenai strategi bersaing produk kredit kepemilikan kendaraan bermotor yang diterapkan perusahaan dan mengadakan pendekatan kepada beberapa bahagian tertentu seperti bagian pemasaran dan bagian keuangan untuk memperoleh data yang berkaitan dengan penelitian ini. b. Wawancara, yaitu penulis melakukan tanya jawab kepada para informan secara langsung untuk memperoleh data berkaitan dengan strategi bersaing produk kredit kepemilikan kendaraan bermotor yang diterapkan perusahaan.

c. Dokumentasi yaitu mengumpulkan data-data tertulis berupa dokumen perusahaan, peraturan-peraturan, jurnal, buku-buku, majalah/surat kabar sehubungan dengan kegiatan pemasaran pada PT Bank Rakyat Indonesia (Persero) Tbk Kantor Wilayah Makassar.

d. Kuesioner penelitian ditujukan kepada responden yang terpilih. Pemilihan responden dilakukan dengan teknik judgment sampling, yaitu dengan cara meminta pendapat dari pelaku (subjek) yang dianggap mampu memberikan informasi yang dibutuhkan. Responden dalam penelitian ini adalah para pengambil kebijakan di bidang penyaluran kredit kendaraan bermotor karena dianggap menguasai dan mengetahui informasi yang dibutuhkan serta para nasabah. Jumlah responden ada 44 (Empat Puluh Empat) orang yang terdiri dari 2 Orang Manajer Pemasaran, 22 Orang Relationship Manajer, 12 Orang Sales, dan 8 Orang Administrasi.

\subsection{Analisis Data}

Metode analisis yang digunakan adalah:

a. Metode analisis deskriptif digunakan untuk mendeskripsikan data hasil penelitian.

b. Metode Analisis SWOT, digunakan untuk mengidentifikasi berbagai faktor guna merumuskan strategi bersaing produk kredit kepemilikan kendaraan bermotor pada PT.Bank Rakyat Indonesia (Persero) Tbk kantor wilayah Makassar dan membandingkan antara faktor eksternal peluang dan ancaman dengan faktor internal kekuatan dan kelemahan.

\section{HASIL DAN PEMBAHASAN}

Kebutuhan akan pembiayaan kepemilikan kredit kendaraan bermotor masyarakat tentu saja akan memberikan keuntungan tersendiri terhadap bank melalui pemberian fasilitas kredit, dalam hal ini memberikan kredit Kepemilikan kendaraan Bermotor (KKB). Menurut Gabungan Industri Kendaraan Bermotor Indonesia (Gaikindo). Penjualan mobil selama 2017 sebanyak 1 juta unit, tahun 20181,1 juta unit dan tahun 2019 sebanyak 1 juta unit. Menurut Gabungan Industri Kendaraan Bermotor Indonesia (GAIKINDO) adanya beragam promo diberikan perusahaan pembiayaan akan menggenjot penjualan kendaraan dari tahunke tahun. Kredit Kendaraan Bermotor dalam dunia perbankan merupakan hal yang baru dalam jenis kredit pebankan termasuk PT Bank Rakyat Indonesia (Persero) Tbk itu sendiri baru menjadi bagian dari produk pada tahun 2004. Sistem Kredit Kendaraan bermotor itu sendiri pada awalnya hanyalah terdapat pada sebuah lembaga pembiayaan non perbankan yang mendapat pengaturan tersendiri. Tetapi kemudian dengan perkembangannya bank mengeluarkan produk baru dalam jenis kreditnya 
yaitu Kredit Kendaraan Bermotor yang secara khusus masuk ke dalam jenis produk kredit bank.

Bertambahnya jenis produk kredit bank ditujukan untuk mengakomodir kebutuhan masyarakat yang semakin lama semakin meningkat dan adanya unsur kepercayaan yang lebih dari masyarakat kepada bank sebagai penyalur kredit (Afdaliana et al., 2019). Kredit kendaraan bermotor yang menjadi salah satu produk kredit PT Bank Rakyat Indonesia (Persero) Tbk yang juga sama halnya dengan jenis kredit lain, yaitu mempunyai ketentuan-ketentuan yang harus dipenuhi terlebih dahulu oleh nasabah dalam hal pengajuan kredit. Kredit jenis baru ini yang diberikan tersebut menggunakan prinsipprinsip pemberian kredit yang ditujukan pada masyarakat Indonesia dengan tetap mengikuti ketentuandari Bank Indonesia mengenai persyaratan uang muka yang dijadikan syarat untuk pengajuan kreditnya.

Kebutuhan masyarakat terhadap kendaraan menciptakan peluang bisnis retail bagi perbankan dengan memberikan produk kredit kepemilikan kendaraan. Produk KKB yang ditawarkan oleh PT Bank Rakyat Indonesia (Persero) Tbk dengan berbagai manfaat dan kelebihannya masing-masing tentu menciptakan persaingan yang ketat, sehingga membuat bank berlombalomba untuk merebut calon debitur dengan berbagaijenis penawaran menarik. Pembiayaan kendaraan masih menjadi sektor yang menarik dan menjadi penggerak bisnis perbankan. Tiap entitas bank dan pembiayaan saling berlomba mengadu strateginya demi memperbesar pangsa pasar yang digarap.

Data Otoritas Jasa Keuangan (OJK) ada sekitar 86 perusahaan pembiayaan, dari total 188 perusahaan, yang bisa menyalurkan pembiayaan kendaraan bermotor dengan uang muka atau down payment (DP) $0 \%-15 \%$. Hal tersebut menunjukkan bahwa persaingan antar pembiayaan dalam memasarkan produk KKB sangat ketat, sehingga membuat setiap bank untuk menjalankan strategi, terutama dalam menjalankan strategi pemasaran yang sanggup bersaing dengan bank maupun lembaga pembiayaan pesaing lainnya. Keadaan ini tentu menimbulkan persaingan tajam antara perbankan karena pesaing yang semakin bertambah. Hal ini juga memaksa perusahaan untuk lebih memperhatikan setiap startegi pemasaran apa dan bagaimana yang harus diterapkan oleh perbankan. Oleh sebab itu, persaingan sangat penting bagi keberhasilan atau kegagalan suatu bank, dimana pesaing dengan menggunakan pendekatan pasar adalah perusahaan-perusahaan yang memuaskan kebutuhan nasabah yang sama. Dengan demikian,PT Bank Rakyat Indonesia (Persero) Tbk tersebut harus lebih cermat membaca serta mengantisipasi keadaan pasar yang dapat memberikan pelayanan berkualitas dan memuaskan nasabah sehingga dapat memenangkan persaingan.

Setiap bank pastinya memiliki strategi pemasaran atau stategi bersaing yang berbeda dengan bank lainnya dalam menghadapi persaingan. Strategi bersaing pada umumnya mempunyai peranan yang sangat penting untuk menghadapi lingkungan yang dinamis, dan pada akhirnya memperoleh keunggulan tertentu/berhasil untuk meningkatkan laba tertentu. Strategi pemasaran menurut Alma (2014) adalah pola keputusan dalam perusahaan yang menentukan dan mengungkapkan sasaran, maksud atau tujuan yang menghasilkan kebijaksanaan utama dan merencanakan untuk pencapaian tujuan serta merinci jangkauan bisnis yang akan dikejar oleh perusahaan. Dengan demikian, strategi pemasaran harus dapat memberi gambaran yang jelas dan terarah tentang apa yang akan dilakukan perusahaan dalam menggunakan setiap kesempatan atau peluang pada beberapa pasar sasaran dalam hal ini dibutuhkan dunia bagian yang sangat penting dan saling berkaitan, untuk mencapai keberhasilan kegiatan pemasaran yang dilakukan oleh suatu perusahaan, yaitu sasaran yang dituju (target market), dan acuan pemasaran yang dijalankan (marketing mix) untuk sasaran pasar tersebut (Assauri, 2015). Strategi bersaing yang ditetapkan harus ditinjau dan dikembangkan sesuai dengan perkembangan pasar dan lingkungan pasar tersebut. Dengan demikian strategi bersaing harus dapat memberi gambaran jelas dan terarah tentang apa yang akan dilakukan perusahaan dalam menggunakan setiap kesempatan atau peluang pada beberapa pasar sasaran. Salah satu analisis strategi pemasaran yang digunakan adalah dengan pendekatan SWOT.

Rangkuti (2015) menyatakan bahwa identifikasi berbagai faktor secara sistematis untuk merumuskan strategi perusahaan. Dengan demikian perencanaan strategis (strategic planner) harus menganalisis faktorfaktorstrategis perusahaan (kekuatan, kelemahan, peluang, dan ancaman) dalam kondisi yangada saat ini. Selanjutnya menurut Akdom (201234), suatu analisis SWOT menghasilkan sejumlah alternatif strategi. Untuk memilih alternatif tersebut organisasi mengevaluasi satu sama lain dengan memperhatikan kemampuan untuk mencapai tujuan.. Adapun data pencairan kredit Kepemilikan Kendaraan Bermotor pada PT Bank Rakyat Indonesia (Persero) Tbk kantor wilayah Makassar dapat dilihat pada Tabel 1 berikut ini.

Tabel 1 Data Pencairan Kredit Kepemilikan Kendaraan Bermotor Pada PT. Bank Rakyat Indonesia (Persero) Tbk Tahun 2015 - 2019

\begin{tabular}{cccc}
\hline Tahun & $\begin{array}{c}\text { Jumlah } \\
\text { Debitur } \\
\text { (orang) }\end{array}$ & $\begin{array}{c}\text { Plafond Kredit } \\
(\mathrm{Rp})\end{array}$ & $\begin{array}{c}\text { SDM } \\
\text { Marketing } \\
\text { (orang) }\end{array}$ \\
\hline 2015 & 632 & 122.568 .799 .221 & 30 \\
\hline 2016 & 723 & 137.213 .466 .053 & 32 \\
\hline 2017 & 561 & 110.236 .333 .996 & 24 \\
\hline 2018 & 504 & 104.502 .313 .703 & 21 \\
\hline 2019 & 426 & 84.812 .198 .485 & 11 \\
\hline Sumber: PT Bank Rakyat & Indonesia (Persero) & Tbk kantor wilayah \\
Makassar, 2019 & & \\
Data pencairan & kredit Kepemilikan & Kendaraan
\end{tabular}
Bermotor pada PT Bank Rakyat Indonesia (Persero) Tbk kantor wilayah Makassar mengalami fluktuasi selama tahun 2015 sampai 2019, yakni tahun 2016 mengalami peningkatan jumlah kredit, plafond kredit, dan jumlah 
SDM marketing. Sedangkan pada tahun 2017 sampai 2019 mengalami penurunan. Hal ini mengindikasikan strategi bersaing produk kredit Kepemilikan Kendaraan Bermotor yang diterapkan PT BRI (Persero) Tbk kantor Wilayah Makassar belum efektif dalam meningkatkan laba perusahaan. Oleh karena itu, perlu memberdayakan pelayanan KKB guna mendukung kebijakan strategi bersaing produk kredit KKB di masa akan datang.

Pelayanan kredit Kepemilikan Kendaraan Bermotor (KKB dapat dilakukan secara langsung kepada user atau melalui kerjasama dengan pihak ketiga seperti Dealer atau Showroom. Kerjasama tersebut harus dituangkan dalam Perjanjian Kerjasama (PKS) yang mengatur hak dan kewajiban masing-masing pihak. Dalam hal pemberian fasilitas KKB, BRI masih kalah bersaing dengan beberapa lembaga pembiayaan. Hal ini dikarenakan BRI masih dikatakan pemain baru dalam hal menyalurkan fasilitas pembiayaan KKB. BRI baru melakukan penjualan produk KKB sejak tahun 2008.

Faktor Internal dan Eksternal Pelaksanaan Strategi Pemasaran

a. Analisis lingkungan internal

1. Produk PT. Bank Rakyat Indonesia (Persero) Tbk Kredit Kepemilikan Kendaraan Bermotor Wilayah Makassar

Kualitas produk memegang peran penting dalam masalah kepuasan konsumen. Pengemasan produk yang baik akan memberikan citra baik perusahaan di mata konsumen. Produk utama PT. Bank Rakyat Indonesia (Persero) Tbk adalah kendaraan bermotor. Produk yang dimiliki perusahaan adalah produk yang baik. Produk yang dimiliki adalah kendaraan dengan tahun pembuatan yang masih baru dengan usia kendaraan kurang dari 5 tahun. Sehingga dapat dipastikan kualitasnya masih terjamin.

2. Penetapan harga produk PT. Bank Rakyat Indonesia (Persero) Tbk Kredit Kepemilikan Kendaraan Bermotor Wilayah Makassar

Harga suatu produk merupakan nilai yang diterima oleh konsumen sebagai pengorbanan yang harus dikeluarkan. Bagi perusahaan harga juga merupakan komponen yang berpengaruh langsung terhadap keuntungan perusahaan. Dalam mematok penetapan harga perusahaan harus mampu menetapkan nilai dimana nilai tersebut berada di tengah antara kemempuan konsumen untuk membeli dan keinginan perusahaan untuk memperoleh laba. PT. Bank Rakyat Indonesia (Persero) Tbk Kredit Kepemilikan Kendaraan Bermotor menetapkan harga jual produk menyesuaikan dengan harga yang ditawarkan oleh perusahaan lain sehingga tidak berdampak citra buruk di mata konsumen dan perusahaan tetap dapat menerima laba seperti yang diperoleh usaha lain.

3. Kegiatan promosi PT. Bank Rakyat Indonesia (Persero) Tbk Kredit Kepemilikan Kendaraan Bermotor Wilayah Makassar
Promosi merupakan kegiatan penting untuk mencapai goal pemasaran produk perusahaan. Promosi dapat dikatakan berhasil apabila produk yang ditawarkan mendapat respon positif dari konsumen. Dalam kegiatan promosi PT. Bank Rakyat Indonesia (Persero) Tbk Kredit Kepemilikan Kendaraan Bermotor Wilayah Makassar ditinjau dari media yang digunakan sudah tepat. Wilayah promosi yang luas didukung dengan media promosi yang dapat diakses dimanapun dan kapanpun akan mempermudah konsumen dalam mengenali produk yang ditawarkan perusahaan.

4. Pelayanan konsumen

Pelayanan yang memuaskan akan meningkatkan omset penjualan produk perusahaan. Konsumen akan merasa senang dan dihargai apabila diberikan pelayanan yang maksimal. PT. Bank Rakyat Indonesia (Persero) Tbk Kredit Kepemilikan Kendaraan Bermotor Wilayah Makassar dalam memberikan pelayanan menggunakan beberapa macam cara.

5. Lokasi perusahaan

Lokasi strategis dapat dilihat atas pertimbangan dimana lokasi perusahaan mudah dijangkau dan diakses oleh konsumen. Pemilihan lokasi PT. Bank Rakyat Indonesia (Persero) Tbk Kredit Kepemilikan Kendaraan Bermotor Wilayah Makassar dinilai cukup strategis sebab perusahaan berada di wilayah konsumen yang memiliki tingkat permintaan yang aktif dan belum terlalu banyak pesaing usaha di bidang yang sama.

6. SDM yang dimiliki perusahaan

Sumber Daya Manusia yang berkualitas akan menunjang kegiatan usaha perusahaan. PT. Bank Rakyat Indonesia (Persero) Tbk Kredit Kepemilikan Kendaraan Bermotor Wilayah Makassar menilai SDM bukan dilihat dari tingkat pendidikan yang tinggi, namun SDM yang berkualitas adalah SDM yang mampu bertanggung jawab atas pekerjaannya.

7. Program pengembangan karyawan

Program pengembangan karyawan berguna untuk meningkatkan kinerja karyawan. Tidak ada kebijakan pengembangan dalam pendidikan karena perusahaan tidak terlalu menuntut karyawannya dalam tingkat pendidikan. Program pengembangan yang PT. Bank Rakyat Indonesia (Persero) Tbk Kredit Kepemilikan Kendaraan Bermotor Wilayah Makassar berikan kepada karyawan berupa pelatihan kerja yang akan memberikan pengalaman lebih baik bagi para karyawan.

8. Sarana dan fasilitas kerja yang dimiliki

Sarana dan fasilitas perusahaan digunakan untuk mendukung kinerja karyawan dalam melakukan pekerjaannya. PT. Bank Rakyat Indonesia (Persero) Tbk Kredit Kepemilikan Kendaraan Bermotor Wilayah Makassar memiliki fasilitas dan sarana yang cukup untuk mendukung kinerja karyawan dan memberikan kenyamanan karyawan saat bekerja, sehingga pada saat ini PT. Bank Rakyat Indonesia 
(Persero) Tbk Kredit Kepemilikan Kendaraan Bermotor Wilayah Makassar tidak memiliki kendala yang berkaitan dengan sarana dan fasilitas kerja.

9. Segmen pasar

Banyak faktor yang mendasari segmentasi pasar untuk sebuah produk. Jenis produk dapat menentukan segmen pasar yang masuk dalam kategori tertentu. Pada PT. Bank Rakyat Indonesia (Persero) Tbk Kredit Kepemilikan Kendaraan Bermotor Wilayah Makassar mngklasifikasikan segmen pasar berdasarkan tingkat pendapatan, kebutuhan,dan status sosial.

10. Penelitian kepada konsumen

Pada kegiatan promosi pasti terdapat kendala dalam memasarkan produk kepada konsumen. Kendala yang dihadapi bisa berasal dari konsumen itu sendiri, contohnya sifat konsumen yang sering berubah mengikuti jaman dan selera konsumen yang berbeda. Untuk mengatasi masalah tersebut maka diperlukan penelitian terhadap konsumen. Program ini bertujuan untuk mengetahui keinginan konsumen dan perilaku konsumen. Namun pada saat ini PT. Bank Rakyat Indonesia (Persero) Tbk Kredit Kepemilikan Kendaraan Bermotor Wilayah Makassar belum melakukan penelitian secara spesifik terhadap konsumen.

b. Analisis lingkungan eksternal

1. Perkembangan teknologi

Perkembangan teknologi akan mempermudah dan memperlancar pelayanan kepada konsumen. Selain itu perkembangan tekhnologi juga dapat menunjang kinerja perusahaan secara keseluruhan. Perkembangan tekhnologi bagi PT. Bank Rakyat Indonesia (Persero) Tbk Kredit Kepemilikan Kendaraan Bermotor Wilayah Makassar berdampak positif dalam menunjang kegiatan usaha.

2. Kebijakan pemerintah

Kebijakan yang dikeluarkan pemerintah seringkali memberi pengaruh besar terhadap perusahaan. Bagi PT. Bank Rakyat Indonesia (Persero) Tbk Kredit Kepemilikan Kendaraan Bermotor Wilayah Makassar kebijakan pemerintah meningkatkan harga bahan bakar minyak bersubsidi mengakibatkan dilema bagi perusahaan dalam menentukan harga produk yang ditawarkan.

3. Pangsa pasar

Menguasai pangsa pasar merupakan prestasi bagi perusahaan.

4. Daya beli masyarakat

Perekonomian nasional yang tidak stabil mengakibatkan penurunan tingkat daya beli konsumen. Hal ini mengakibatkan konsumen cenderung untuk mengutamakan kebutuhan primernya yang lebih mendesak.

c. Analisis SWOT

Data dari perusahaan PT. Bank Rakyat Indonesia (Persero) Tbk Kredit Kepemilikan Kendaraan Bermotor
Wilayah Makassar yang telah dikumpulkan dan dilakukan analisis pada faktor internal dan eksternal kemudian digunakan untuk menentukan faktor strategis perusahaan untuk analisis SWOT. Faktor internal dan eksternal pelaksanaan pada PT. Bank Rakyat Indonesia (Persero) Tbk Kredit Kepemilikan Kendaraan Bermotor Wilayah Makassar sebagai berikut:

1. Kekuatan

a) Kualitas produk yang ditawarkan baik

b) Harga produk yang ditetapkan terjangkau konsumen

c) Pengaruh lokasi terhadap kelangsungan usaha yang baik

d) Pelayanan kepada konsumen yang maksimal

e) Jaminan kualitas produk yang baik pada konsumen

f) Kerjasama yang baik antara perusahaan dengan pihak asuransi

2. Kelemahan

a) Tingkat harga kredit kendaraan yang ditawarkan

b) Resiko penurunan pendapatan yang tinggi

c) Keterbatasan jumlah karyawan yang tinggi

3. Peluang

a) Kemampuan menangkap pangsa pasar yang baik

b) Jalinan kerjasama perusahaan dengan konsumen yang baik

c) Dampak positif dari keragaman produk yang ditawarkan

d) Citra perusahaan yang baik dimata konsumen

e) Respon positif konsumen terhadap jasa perusahaan

f) Tingkat daya beli masyarakat

g) Tingkat permintaan pasar

4. Ancaman

a) Tingkat persaingan usaha yang tinggi

b) Resiko usaha jasa kredit kendaraan yang tinggi

c) Resiko pekerja freelance yang tinggi

d) Tuntutan pasar dalam peremajaan kendaraan yang tinggi

e) Tingkat kriminalitas pencurian kendaraan yang tinggi

f) Tingginya pertumbuhan usaha Kredit Kendaraan disekitar

\section{d. Pemberian Bobot dan Rating}

Pemberian bobot pada faktor internal dan eksternal didasarkan pada penyebaran angket yang telah dilakukan pada karyawan PT. Bank Rakyat Indonesia (Persero) Tbk Kredit Kepemilikan Kendaraan Bermotor Wilayah Makassar. Rata-rata dari faktor internal dan eksternal yang diperoleh atas pendapat karyawan sebagai berikut:

\section{Kekuatan}

Data diperoleh dari hasil penjumlahan skor setiap indikator kekuatan pada seluruh responden kemudian dibagi dengan jumlah keseluruhan responden yang berjumlah 44 responden. Nilai bobot rata-rata 4,5 yang memiliki arti setiap responden memberikan nilai pada Faktor kekuatan baik hingga sangat baik. 
Tabel 2 Indikator Bobot Kekuatan

\begin{tabular}{clcc}
\hline No & \multicolumn{1}{c}{ Indikator } & Jumlah & Bobot \\
\hline 1 & Kualitas produk yang ditawarkan baik & 192 & 4,4 \\
2 & Harga produk yang ditetapkan terjangkau konsumen & 203 & 4,6 \\
3 & Pengaruh lokasi terhadap kelangsungan usaha yang & 195 & 4,4 \\
& baik & & \\
4 & Pelayanan kepada konsumen yang maksimal & 195 & 4,4 \\
5 & Jaminan kualitas produk yang baik pada konsumen & 197 & 4,5 \\
6 & Kerjasama yang baik antara perusahaan dengan & 201 & 4,6 \\
& pihak asuransi & & \\
\hline \multicolumn{2}{r}{ Rata - Rata Bobot } & 4,5 \\
\hline
\end{tabular}

2. Kelemahan

Data diperoleh dari hasil penjumlahan skor setiap indikator kelemahan pada seluruh responden kemudian dibagi dengan jumlah keseluruhan responden yang berjumlah 44 responden. Nilai bobot rata-rata 4, 1 yang memiliki arti setiap responden memberikan nilai pada Faktor kelemahan Baik hingga Sangat Baik.

Tabel 3 Indikator Bobot Kelemahan

\begin{tabular}{clcc}
\hline No & \multicolumn{1}{c}{ Indikator } & Jumlah & Bobot \\
\hline 1 & Tingkat harga kredit kendaraan yang ditawarkan & 175 & 4 \\
\hline 2 & Resiko penurunan pendapatan yang tinggi & 174 & 4 \\
\hline 3 & Keterbatasan jumlah karyawan yang tinggi & 192 & 4,4 \\
\hline \multicolumn{2}{c}{ Rata - Rata Bobot } & & 4,1 \\
\hline & Peluang
\end{tabular}

3. Peluang

Data diperoleh dari hasil penjumlahan skor setiap indikator peluang pada seluruh responden kemudian dibagi dengan jumlah keseluruhan responden yang berjumlah 44 responden. Nilai bobot rata-rata 4,4 yang memiliki arti setiap responden memberikan nilai pada Faktor peluang baik hingga sangat baik.

Tabel 4 Indikator Bobot Peluang

\begin{tabular}{clcc}
\hline No & \multicolumn{1}{c}{ Indikator } & Jumlah & Bobot \\
\hline 1 & Kemampuan menangkap pangsa pasar yang baik & 204 & 4,6 \\
2 & $\begin{array}{l}\text { Jalinan kerjasama perusahaan dengan konsumen } \\
\text { yang baik }\end{array}$ & 196 & 4,5 \\
3 & $\begin{array}{l}\text { Dampak positif dari keragaman produk yang } \\
\text { ditawarkan }\end{array}$ & 196 & 4,5 \\
4 & $\begin{array}{l}\text { Citra perusahaan yang baik dimata konsumen } \\
5\end{array}$ & 199 & 4,5 \\
& $\begin{array}{l}\text { Respon positif konsumen terhadap jasa } \\
\text { perusahaan }\end{array}$ & 188 & 4,3 \\
6 & Tingkat daya beli masyarakat & 191 & 4,3 \\
7 & Tingkat permintaan pasar & 194 & 4,4 \\
\hline \multicolumn{4}{r}{ Rata - Rata Bobot } \\
\hline
\end{tabular}

4. Ancaman

Data diperoleh dari hasil penjumlahan skor setiap indikator ancaman pada seluruh responden kemudian dibagi dengan jumlah keseluruhan responden yang berjumlah 44 responden. Nilai bobot rata-rata 3,9 yang memiliki arti setiap responden memberikan nilai pada Faktor ancaman cukup hingga baik.

Tabel 5 Indikator Bobot Ancaman

\begin{tabular}{rlcc}
\hline No & \multicolumn{1}{c}{ Indikator } & Jumlah & Bobot \\
\hline 1 & Tingkat persaingan usaha yang tinggi & 192 & 4,4 \\
2 & Resiko usaha jasa kredit kendaraan yang tinggi & 168 & 3,8 \\
3 & Resiko pekerja freelance yang tinggi & 162 & 3,7 \\
4 & $\begin{array}{l}\text { Tuntutan pasar dalam peremajaan kendaraan yang } \\
\text { tinggi }\end{array}$ & 181 & 4,1 \\
5 & $\begin{array}{l}\text { Tingkat kriminalitas pencurian kendaraan yang } \\
\text { tinggi }\end{array}$ & 150 & 3,4 \\
6 & $\begin{array}{l}\text { Tingginya pertumbuhan usaha Kredit Kendaraan } \\
\text { disekitar }\end{array}$ & 175 & 4,0 \\
\hline & & & 3,9 \\
\hline
\end{tabular}

Jumlah total bobot yang dimasukkan dalam tabulasi tidak boleh melebihi satu (1), sehingga unntuk menghasilkan nilai yang sesuai dengan teori maka nilai bobot tersebut dilakukan perhitungan sebagai berikut.

Tabel 6 Faktor Internal (Kekuatan dan Kelemahan)

\begin{tabular}{|c|c|c|c|c|}
\hline & Faktor Strategis & Bobot & Rating & Skor \\
\hline \multirow{6}{*}{ Kekuatan } & $\begin{array}{l}\text { Kualitas produk yang ditawarkan } \\
\text { baik }\end{array}$ & 0,11 & 4,4 & 0,49 \\
\hline & $\begin{array}{l}\text { Harga produk yang ditetapkan } \\
\text { terjangkau konsumen }\end{array}$ & 0,12 & 4,6 & 0,54 \\
\hline & $\begin{array}{l}\text { Pengaruh lokasi terhadap } \\
\text { kelangsungan usaha yang baik }\end{array}$ & 0,11 & 4,4 & 0,49 \\
\hline & $\begin{array}{l}\text { Pelayanan kepada konsumen yang } \\
\text { maksimal }\end{array}$ & 0,11 & 4,4 & 0,49 \\
\hline & $\begin{array}{l}\text { Jaminan kualitas produk yang baik } \\
\text { pada konsumen }\end{array}$ & 0,11 & 4,5 & 0,52 \\
\hline & $\begin{array}{l}\text { Kerjasama yang baik antara } \\
\text { perusahaan dengan pihak asuransi }\end{array}$ & 0,12 & 4,6 & 0,54 \\
\hline \multirow{4}{*}{ Kelemahan } & $\begin{array}{l}\text { Tingkat harga kredit kendaraan yang } \\
\text { ditawarkan }\end{array}$ & 0,10 & 4 & 0,41 \\
\hline & $\begin{array}{l}\text { Resiko penurunan pendapatan yang } \\
\text { tinggi }\end{array}$ & 0,10 & 4 & 0,41 \\
\hline & $\begin{array}{l}\text { Keterbatasan jumlah karyawan yang } \\
\text { tinggi }\end{array}$ & 0,11 & 4,4 & 0,4 \\
\hline & Total & 1,00 & & 4,38 \\
\hline
\end{tabular}

Sumber: Hasil Analisis SWOT

Tabel 7 Faktor Eksternal (Peluang dan Ancaman)

\begin{tabular}{|c|c|c|c|c|}
\hline & Faktor Strategis & Bobot & Rating & Skor \\
\hline \multirow{7}{*}{ Peluang } & $\begin{array}{l}\text { Kemampuan menangkap pangsa } \\
\text { pasar yang baik }\end{array}$ & 0,08 & 4,6 & 0,39 \\
\hline & $\begin{array}{l}\text { Jalinan kerjasama perusahaan } \\
\text { dengan konsumen yang baik }\end{array}$ & 0,08 & 4,5 & 0,37 \\
\hline & $\begin{array}{l}\text { Dampak positif dari keragaman } \\
\text { produk yang ditawarkan }\end{array}$ & 0,08 & 4,5 & 0,37 \\
\hline & $\begin{array}{l}\text { Citra perusahaan yang baik dimata } \\
\text { konsumen }\end{array}$ & 0,08 & 4,5 & 0,37 \\
\hline & $\begin{array}{l}\text { Respon positif konsumen terhadap } \\
\text { jasa perusahaan }\end{array}$ & 0,08 & 4,3 & 0,34 \\
\hline & Tingkat daya beli masyarakat & 0,08 & 4,3 & 0,34 \\
\hline & Tingkat permintaan pasar & 0,08 & 4,4 & 0,36 \\
\hline \multirow{7}{*}{ Ancaman } & $\begin{array}{l}\text { Tingkat persaingan usaha yang } \\
\text { tinggi }\end{array}$ & 0,08 & 4,4 & 0,36 \\
\hline & $\begin{array}{l}\text { Resiko usaha jasa kredit kendaraan } \\
\text { yang tinggi }\end{array}$ & 0,07 & 3,8 & 0,26 \\
\hline & Resiko pekerja freelance yang tinggi & 0,07 & 3,7 & 0,25 \\
\hline & $\begin{array}{l}\text { Tuntutan pasar dalam peremajaan } \\
\text { kendaraan yang tinggi }\end{array}$ & 0,08 & 4,1 & 0,31 \\
\hline & $\begin{array}{l}\text { Tingkat kriminalitas pencurian } \\
\text { kendaraan yang tinggi }\end{array}$ & 0,06 & 3,4 & 0,21 \\
\hline & $\begin{array}{l}\text { Tingginya pertumbuhan usaha } \\
\text { Kredit Kendaraan disekitar }\end{array}$ & 0,07 & 4 & 0,29 \\
\hline & Total & 1,00 & & \\
\hline
\end{tabular}

Sumber: Hasil Analisis SWOT

Hasil analisis data SWOT pada PT. Bank Rakyat Indonesia (Persero) Tbk Kredit Kepemilikan Kendaraan Bermotor Wilayah Makassar maka dapat dijabarkan sebagai berikut:

a. Kondisi internal PT. Bank Rakyat Indonesia (Persero) Tbk Kredit Kepemilikan Kendaraan Bermotor Wilayah Makassar dapat dilihat pada tabel 4.8 yang bernilai 4,38 diperoleh dari penjumlahan bobot item pada masing-masing indikator faktor kekuatan dan kelemahan penilaian responden dikalikan rating masing-masing indikator. Kondisi internal PT. Bank Rakyat Indonesia (Persero) Tbk Kredit Kepemilikan Kendaraan Bermotor Wilayah Makassar dinyatakan baik karena nilai rata-rata 
faktor kekuatan perusahaan lebih tinggi dibandingkan nilai rata-rata kelemahan perusahaan.

b. Kondisi eksternal PT. Bank Rakyat Indonesia (Persero) Tbk Kredit Kepemilikan Kendaraan Bermotor Wilayah Makassar dapat dilihat pada tabel 4.9 yang bernilai 4,22 diperoleh dari penjumlahan bobot item pada masing-masing indikator faktor peluang dan ancaman penilaian responden dikalikan rating masing-masing indikator. Kondisi eksternal PT. Bank Rakyat Indonesia (Persero) Tbk Kredit Kepemilikan Kendaraan Bermotor Wilayah Makassar dinyatakan baik karena nilai rata-rata factor peluang perusahaan lebih tinggi dibandingkan nilai rata-rata kelemahan perusahaan.

Terdapat 4 faktor yang memiliki pengaruh besar strategi bersaing produk Kredit Kredit Kendaraan Bermotor.

a. Faktor kekuatan

Harga produk yang ditetapkan terjangkau konsumen memiliki pengaruh besar, hal tersebut tidak terlepas dari bunga kredit kendaraan yang ditawarkan oleh Bank BRI masih jauh lebih murah dibanding pesaing sehingga menjadi pilihan utama oleh konsumen .

b. Faktor kelemahan

Keterbatasan jumlah karyawan berpengaruh penting dalam menunjang kegiatan usaha, hal tersebut bisa dilihat dengan adanya penurunan jumlah tenaga pemasar pada 4 (empat) tahun terakhir yang menyebabkan realisasi dan plafond kredit berkurang.

c. Faktor Peluang

Peluang bisnis yang berpengaruh yakni perusahaan memiliki keunggulan dalam menangkap pangsa pasar yang baik, hal tersebut bisa dilihat banyaknya perusahaan -perusahaan BUMN, BUMD, Dealer maupun showroom yang bekerja sama dengan Perusahaan dalam hal pemberian kredit kepemilikan kendaraan bermotor serta kemampuan perusahaan dalam memfasilitasi konsumen dari perkotaan hingga pedesaan.

d. Faktor ancaman

Tingkat persaingan usaha yang tinggi harus menjadi perhatian yang serius hal tersebut disebabkan banyaknya bermunculan pembiayaan yang menawarkan proses kredit kendaraan yang mudah (tanpa BI Cheking/Slik, Dp 0\%, tanpa survey).

\section{Strategi SO (strength dan opportunities)}

Strategi ini dilakukan untuk memanfaatkan kekuatan perusahaan guna menangkap peluang yang dimiliki perusahaan. Menggunakan media promosi yang tepat sasaran sesuai pasar yang akan dituju oleh perusahaan sehingga tepat sasaran. Melakukan inovasi terhadap jenis produk yang ditawarkan dan menjamin kualitas produk yang ditawarkan serta memberikan pelayanan yang maksimal kepada konsumen untuk mendapatkan citra baik perusahaan dimata konsumen.

Strategi ST (strength dan treats)
Strategi ini diterapkan dimana kekuatan yang dimiliki perusahaan digunakan untuk mengatasi ancaman yang mungkin dapat dihadapi PT. Bank Rakyat Indonesia (Persero) Tbk Kredit Kepemilikan Kendaraan Bermotor Wilayah Makassar. Perusahaan dapat menetapkan harga yang bersaing untuk menghindari ancaman dari tumbuhnya usaha dibidang yang sama serta perushaan akan unggul apabila kendaraan yang ditawarkan adalah kendaraan dengan tahun pembuatan baru. Perusahaan juga harus menguatkan citra baik dimata konsumen agar usaha yang dijalankan PT. Bank Rakyat Indonesia (Persero) Tbk Kredit Kepemilikan Kendaraan Bermotor Wilayah Makassar tetap konsisten.

\section{Strategi WO (weakness dan opportunities)}

Strategi ini diterapkan pada saat adanya peluang yang dimiliki perusahaan guna mengatasi ancaman usaha. Perusahaan harus melakukan inovasi untuk menangkap peluang yang ada agar mempunyai karakter dimata konsumen, serta menetapkan harga produk yang kompetitif agar tidak kalah dengan perusahaan lain. Perusahaan juga perlu melakukan peremajaan pada kendaraan sesuai dengan kebutuhan pasar saat ini dan perlu adanya pengamanan pada kendaraan agar meminimalkan resiko tindak kejahatan pada pencurian kendaraan.

\section{Strategi WT (weakness dan treats)}

Strategi ini diterapkan saat perusahaan harus mampu mengatasi kelemahan yang dimiliki perusahaan agar terhindar dari ancaman usaha yang akan dihadapi. Perusahaan harus mampu mencukupi kekurangan kendaraan dan karyawan yang menjadi kekurangan dari perusahaan. Fokus dalam membidik pangsa pasar agar tujuan dari perusahaan dapat terpenuhi terlebih dahulu. Pemilihan karyawan tidak tetap sesuai dengan keahlian namun dapat dipercaya kinerjanya misalkan dengan rekomendasi Strategi pemasaran yang tepat diterapkan pada PT. Bank Rakyat Indonesia (Persero) Tbk Kredit Kepemilikan Kendaraan Bermotor Wilayah Makassar untuk saat ini adalah menerapkan strategi SO (strength Opportunities).

\section{SIMPULAN}

Hasil penelitian dan pembahasan, maka dapat ditarik kesimpulan bahwa faktor kekuatan (internal) yakni harga produk yang ditetapkan terjangkau konsumen memiliki skor nilai tinggi dibandingkan kualitas produk yang ditawarkan, pengaruh lokasi terhadap kelangsungan usaha, pelayanan kepada konsumen, jaminan kualitas produk, dan kerjasama yang baik dengan pihak asuransi. Sedangkan pada faktor kelemahan (internal) yakni keterbatasan jumlah karyawan yang tinggi memiliki skor paling tinggi dibadingkan dengan tingkat harga kredit kendaraan yang ditawarkan dan resiko penurunan pendapatan yang tinggi. Untuk faktor Peluang (eksternal) yang memiliki skor paling tinggi yakni perusahaan memiliki keunggulan dalam menangkap pangsa pasar yang baik dibandingkan dengan jalinan kerjasama 
perusahaan dengan konsumen, dampak positif dari keragaman produk yang ditawarkan, citra perusahaan yang baik dimata konsumen, respon positif konsumen terhadap jasa perusahaan, tingkat daya beli masyarakat, dan tingkat permintaan pasar.Sedangkan untuk faktor ancaman (eksternal) yakni tingkat persaingan usaha yang tinggi memiliki skor paling tinggi dibandingkan resiko usaha jasa kredit kendaran yang tinggi, resiko pekerja freelance yang tinggi, tuntutan pasar dalam peremajaan kendaraan yang tinggi, tingkat kriminalitas pencurian kendaraan yang tinggi dan tingginya pertumbuhan usaha kredti kendaraan disekitar.Secara garis besar dari ke empat faktor tersebut faktor Kekuatan dan Peluang masih memiliki skor yang lebih tinggi dibandingkan dengan faktor Kelemahan dan Ancaman sehingga PT Bank Rakyat Indonesia (Persero) Tbk berada dalam posisi yang baik.

\section{DAFTAR PUSTAKA}

Afdaliana, A., Saleh, M. Y., \& Sapiri, M. (2019). Analisis Sumber Dan Penggunaan Dana Berbasisteknologi Digital Terhadap Profitabilitas Studi Kasus Pada Pt Bank Rakyat Indonesia (Persero) Tbk Kantor Cabang Makassar Panakkukang. Indonesian Journal of Business and Management, 1(2), 1-8.

Akdon, Riduwan. 2012. Rumus dan Data dalam Aplikasi Statistika. Cetakan 1. Bandung: Alfabeta.

Alma, B. 2014. Manajemen Pemasaran dan Pemasaran Jasa. Alfabeta, Bandung

Assauri, Sofjan. Manajemen Pemasaran, (Jakarta: Rajawali Pers, 2015), hlm.167-168.

Fuady, Munir. 2002. Hukum Tentang Pembiayaan Konsumen, PT. Citra Aditya Bakti, Bandung,

Rangkuti, Freddy. 2014. Analisis Swot Teknik Membedah Kasus Bisnis. PT. Gramedia Pustaka Utama : Jakarta.

Rangkuti, Freddy. 2015.Analisis SWOT Teknik Membedah Kasus Bisnis, Cetakan Keduapuluh, Penerbit : Gramedia Pustaka Utama. Jakarta

Sugiyono. (2016). Metode Penelitian Kuantitatif, Kualitatif dan R\&D. Bandung: Alfabeta 